\title{
Quality Education Management and Teaching Quality
}

\author{
Frank Viana Carvalho ${ }^{1 *}$, Ricardo dos Santos Coelho \\ ${ }^{l}$ PhD in Philosophy at University of São Paulo, Brazil. \\ ${ }^{2} \mathrm{PhD}$ in Environmental Engineering at University of São Paulo, Brasil.
}

*Corresponding Author: Frank Viana Carvalho, PhD in Philosophy at University of São Paulo, Brazil.

\begin{abstract}
In education, as in other areas, the search for quality is a constant in this world of rapid changes, marked, above all, by information technologies. However, if in one hand there is a real search for educational quality and a renewed interest in the growth of teaching quality, on the other hand, the concern with the distortion of the concept due to quantitative goals overrides the application of measures that guarantee the desired real quality. If it is a challenge to conceptualize quality, it is also to manage this process and verify the political and social nuances that blends with the proposals for educational quality.
\end{abstract}

Keywords: Educational Quality, Teaching Quality, Educational Quality Management, Educational Policies, Quality School.

\section{INTRODUCTION}

Talking about quality teaching at a time of great changes in society and education is not an easy task. Largely, the second decade of the 21st century ends digital society revolves around quality and its demand is not an issue that we could not simply ignore.

Quality teaching or even educational quality as a whole, are not abstract or intangible values. They are, above all, perceptible values and their effects are perceived and felt in different spheres of education. It may be that for some it is comfortable to treat the quality teaching or educational quality as abstract and inaccessible, relativizing its concept and application, perhaps because they do not want to submit their efforts to a qualitative evaluation, or who knows, they have never seen education as worthy the efforts in that direction.

\section{DEFINITIONS}

The Guidelines and Bases of Education Law (9394/96) establishes that one of the guiding principles of teaching is its "guarantee of quality standard" (art. 3, Item IX). Just before the enactment of this law, Rinehart already said that "the disparity of concepts makes it extremely difficult to develop a common concept for educational quality", but despite this, "the search for a consensual concept is necessary for a deep exploration of the theme" (RINEHART, 1993, p. 46). Neiva (1994) seemed to seek a concept of the world of work when he stated "the quality of a school is to be suitable for use", and he himself asked and answered: "suitable for whom? For the client: (...) the people affected by the school, its clients: parents, students, teachers, employees, institutions, people from the community ... "(p. 112). On the other hand, Mezomo (1994) seems to go far beyond this view when he states that "quality at school is not a business, it is a process developed by, and for people for the benefit of the whole of society" (1994, p. 13). And he adds:

"That is why school's quality depends on the knowledge of the needs and expectations of its external customers, whose service must be the basic concern of those who are known as its internal customers: principals, teachers and administrative and auxiliary personnel." (MEZOMO, 1994, p. 15).

But the very idea of quality presupposes a development, of change, without, of course, disregarding the contributions of the past. Enguita (1995) already stated that "each new version of quality does not 
replace entirely and once and for all the previous ones", because "the new version moves the old ones aside, but has to live with them" (ENGUITA in Gentili, 1995, pages 98 and 99).

But it is important to highlight that quality education has many aspects and nuances, which is why Sandrini emphasizes that "quality school is a diversified school that does not work with prejudices or with unified curriculum", and adds, "teaching with pleasure, takes pleasure in learning, this is teaching quality "(SANDRINI, 1994, pp. 27 and 32).

Almost at the turn of the 20th century to the 21st, following a trend established in the 1988 Brazilian Constitution, which provided for ten-year plans for education, from the first plan (Ten-Year Plan for Education for All 1993-2003), there was a perspective of educational quality:

"The Decennial Education Plan, in line with what is established in the 1988 Constitution, affirms the need and obligation for the State to develop clear parameters in the curricular field capable of guiding the educational actions of compulsory education, in order to adapt it to the democratic ideals and the pursuit of improving the teaching quality in Brazilian schools"(PCN, 1997, p. 14). [Our emphasis.]

In the following plan, in the pursuit of educational quality, actions to finance education allowed guaranteed budget to improve conditions with the creation of FUNDEF, later transformed into FUNDEB. FUNDEF - Fund for Maintenance and Development of Elementary Education and Valorization of Teaching - created in 1996 (effective in 1998) was in force until 2006, when it was replaced by the Fund for Maintenance and Development of Basic Education and Valorization of Education Professionals (Fundeb), which will end in 2020.

As we have seen, there is no single definition of teaching quality and it cannot be said that one definition is, in essence, better than the others. Yes, there are more comprehensive and complete definitions, which take into account a greater number of components of this qualitative process. The education quality has several components, which, when integrated, make what we call quality education. In public education, it necessarily involves public educational policies.

\section{Educational Policies and Quality in Education}

Some years later, Dourado, Oliveira and Santos (2007) sought to expand these reference standards of educational quality by defining limits and standards with regard to public education. Firstly, from those who are the target of education - the students, their parents and the community - showed that there is an objective needed to establish public policies, actions and projects to face all issues involving good education that will lead to integral development and meaningful learning. From then on, as there is this need, there is also an obligation of the State to offer and guarantee quality standards.

To this end, they indicate four intra-school dimensions in educational quality that are reflected in the teaching quality: a) the system plan - the conditions of teaching provision (facilities, environment, equipment, physical space, collections, quantities, programs, costs and materials); b) the school plan - school work management and organization (organizational structure, pedagogical work, planning, institutional evaluation, democratic and participative management, integration and participation mechanisms, leaders, pedagogical project, school autonomy, pedagogical and curricular activities, teachers , curriculum, technologies, teaching and learning processes); c) the teacher's plan (training, pedagogical action, qualification/qualification, bond, career, appreciation, experience, progression, workload, continuing education, motivation); d) the student's plan (access, permanence, performance, colleagues, teachers, learning, groups, perception, teaching and learning process, educational conditions, expectations of success).

There is no doubt that establishing parameters for educational quality can lead to quantitative digressions in educational policies that will have positive or negative qualitative impacts. Oliveira and Araújo shows that these political issues can interfere and direct the definition and scope of this desired quality:

“(...) the task of defining quality indicators is not only technical, but also political, that is, defining inputs and parameters for quality education requires an analysis of costs, of the real conditions, of the objectives that are sought and social expectations surrounding the schooling process. (2005, p. 18). 
In order to meet the statistical demands, the direction of quality may suffer distortions, or measures of dubious results, when the question is the search for teaching quality or educational quality. In this specific case, Oliveira and Araújo (2005), emphasize that many policies aimed only at improving the numbers, statistics or productivity of the system, and not the question of quality itself, and there they can be questionable in terms of quality:

"The adoption of cycles, automatic promotion and programs to accelerate learning have an impact on the issue of lack of quality, avoiding the internal mechanisms of school selectivity that consisted basically of failure and exclusion by expulsion "accounted" as evasion. It can be discussed whether these policies and programs have the effect of improving teaching. In fact, its great impact can be seen in the indices used until then to measure the efficiency of education systems, not directly affecting the problem.” (OLIVEIRA and ARAÚJO, 2005, p. 11).

\section{QUALITY ASSESSMENT}

Quality assessment does not necessarily involve quantitative measurement, or a linear glimpse of numbers. It should be noted that at all times the education quality is under the scrutiny of educators, parents, students, the community, and other observers. And they are constantly exposing their perceptions and analyzes about the educational quality of school institutions. It should be noted that descriptive analyzes are qualitative measurements. They are not presented as numbers, but as descriptions or impressions of what you can see, feel or perceive. If we consider the value of these descriptions and their importance as an object of evaluation and improvement of the services provided, we will have a view of direct and indirect perceptions of quality in education and of education in a tangible way.

A teaching institution that has quality teaching did not conquer it by chance of the educational destiny. The sum of competence, coupled with constant planning and team engagement in relation to the proposed targets made this possible.

We, the authors of this article, believe that when it comes to quality in education, its peculiarities are beyond the concept, scope and context of the word 'quality' when used in the business world. Although it is possible to adapt the quality of the world of work to its reality, the school and its context show that adaptations cannot be made indiscriminately, since each school, college and university has its own reality, marks and specificities. And for this, the focus on the student, his academic and professional training, the construction of his values, his personal and professional skills must be taken into account in these particular contexts. And with regard to the work of the educational and administrative team, the various forms of management of the team, their daily activities, their engagement, their responsibility and commitment to the institution's mission. All of this will have an impact on making educational quality in each school. Successful models in some school institutions can be applied in other institutions, as long as there is adaptation and commitment of the team to the educational quality project. Other important factors in this process would be material and structural conditions, individual responsibility and team work.

A quality educational institution cannot neglect the preparation and continued training of its employees. In addition to participation in symposia, seminars, congresses, courses and short courses, in the institution itself and outside it, and the possibility of broad and strictu sensu studies, the exchange of experiences, reflections and continuous learning with each other also enter this pedagogical training praxis.

The quality of teaching is complete and established in the relationship between teacher and student. In this teaching and learning dialectic, as in a two-way road, interaction creates and allows productive interrelationships of knowledge and companionship, of encouragement and partnership, of research and renewal of knowledge, of continual learning.

The quality of education and the quality of teaching are demonstrated in the school's interaction with the community. In public schools, in their democratic relationships of leadership and participation, insertion in the community and valuing it. In the private school, in the dialogue without borders and in the many expressions of solidarity, help and growth, which go beyond the vision of the world of work, dividends and cash flow. 
Quality school is a school of participation and respect. Respect for individual differences, when living and practicing inclusion. It is a school of respect for the rights of others, an institution that knows and understands otherness. The individual space is valued and the space of the other is also, therefore a school of autonomy, freedom and limits in its correct meanings. Autonomy as a goal of education in human formation, freedom in creation and opportunities, and limits for the student to learn to live in harmony with others and with himself.

Educational quality is not supported by technological advances as its greatest strength, but wisely makes use of these resources. It uses them as pedagogical tools in the continuous students updating to the world that he already lives and will find when he leaves the academy.

Modern teaching methodologies are pedagogical tools, paths to quality school, and not the end. They can guarantee better learning, more complete views of the world and knowledge.

\section{A Proposal}

Is it possible to recognize the quality of teaching in a school or classroom? Here is a model based on Carvalho (2000, p. 151-153), a proposal, or even a suggestion for the quality school and for the quality classroom. At times and moments of so many lists, may these not be just an extra role.

\subsection{A Quality School with Teaching Quality}

1. It is concerned with the complete formation of the human being. It sees the student as an integral human being, not dichotomized, but multiple and with potential. It seeks to develop its physical, social, cognitive, affective, spiritual and emotional aspects.

2. Has your education focused on building citizenship. It seeks to develop solidarity and participation.

3. It seeks to give the student the critical awareness formation. It is necessary to see the world with attentive eyes and see behind appearances. But this is also a participatory awareness, as it sees problems as opportunities for solutions.

4. Values the work of teachers and school staff. Recognizes the importance of the teaching role in students training. It treats the professional with respect and dignity, always valuing him, inside and outside the classroom.

5. Seeks to improve resources and technologies. You know that these are not the basis of quality, but you are aware of how much this can help to strengthen the quality of teaching.

6. Challenges students to work in teams and groups. It is not afraid of the exchange of experiences and the growth that this provides. Motivates interaction and the development of interpersonal skills.

7. It is a school of learning: learn to learn, learn to do, learn to share, learn to be.

8. It relates and interacts with the community. It is not a closed school, isolated from the surrounding community. This relationship is conscious, the result of planning and concrete activities, not empty proposals and disguised attitudes.

9. It is a school where "knowledge" is not restricted to curricular content, but expands to competences, attitudes, values and skills.

10. It is the school of integration between theory and practice through everyday life in the classroom and through the many events that the school promotes throughout the school year.

\subsection{A Classroom with Teaching Quality}

1. The teacher constantly seeks to add value to knowledge, relating it to practical life and real problems.

2. Its center of operation is learning to learn. This will be a differential factor in the challenges that life will pose to the student.

3. It is strong in cooperation due to the dynamics of work and the organization of students in the classroom. Students work in different ways on different occasions in order to strengthen their 
interaction and expand their knowledge: in pairs, in small groups and large groups, and also individually.

4. The interaction between teacher-students, and students-students is always positive, with cordiality, respect and appreciation for the teacher's work and, on the other hand, equal opportunities for participation for all.

5. The assessment is continuous, descriptive and progressive. It is never an end in itself, but a diagnosis and report, always considering the students' potential, without labeling them positively or negatively. The assessment is also broad, using several means to verify and from there reinforce the students' learning.

6. The teacher continuously and progressively makes use of resources, materials, spaces and equipment that will assist him in the task of teaching and sharing knowledge.

7. The teacher uses active teaching and learning methodologies. He does not become a hostage to them, but makes the most of the pedagogical potential they offer.

8. The teacher works considering the individual differences: the different skills, intelligences, worldviews and ways of learning. Thus, he seeks to get to know his students to help them discover and grow.

9. Students are constantly challenged to demonstrate what they have learned and to share their knowledge, through normal classes and in many projects that the school carries out.

10. It is a small community of multiple relationships and growth. It is the place of equals and different. Citizenship and participation. Learning and discoveries. Wise and ignorant, this is because nobody knows everything, we all ignore something, and nobody knows anything: we all know something.

\section{CONCLuSion}

Teaching quality is that education aimed at the formation of the integral human being: rich in the formal aspect, seeking to give skills and knowledge necessary for individual growth, making the student actively participate in the construction of his knowledge, for his full intellectual development, above all by learning to learn; rich in the political aspect, making the student a thinking, autonomous and critical individual, but at the same time participant and engaged in the constant improvement of society as a whole, focusing on learning to participate; rich in the affective and social aspect, where the student learns to value himself and others, developing in a positive way his self-esteem, his skills, his values, and the skills of inter-relationship, being supportive, understanding and cooperative , standing out for learning to be and learning to share.

Yes, the quality of teaching can be a concrete, tangible and perceptible value. It is a challenge facing all of us educators. As managers, teachers, students, parents and the educational community, we have in ourselves the pursuit of this desired quality. It is not a challenge for tomorrow, but for today and now, in the hope of building a better, fairer and better-prepared nation for the great challenges at the end of the second decade of the 21 st century.

\section{REFERENCES}

[1] BRAZIL. National Education Guidelines and Bases Law. Law No. 9,394 of December 20, 1996.

[2] CARVALHO, Frank Viana. Quality assessment applied to educational processes. Master's Dissertation presented to the Faculty of Education at UNASP, Concentration Area: "Teaching Methodology". Advisor Dr. Lucila Schwantes Arouca. UNASP, ENGENHEIRO COELHO - SP, 2000.

[3] DOURADO, L.F.; OLIVEIRA, J.F.; SANTOS, C.A. The quality of education: concepts and definitions. Documental Series: Texts for Discussion, Brasília, DF, v. 24, n. 22, p. 5-34, 2007.

[4] GENTILI, P.; SILVA, Tomaz Tadeu., ENGUITA, Mariano Fernández, et all. Neoliberalism, total quality and education. 2nd Ed., Petrópolis: Vozes, 1995.

[5] MEZOMO, João Catarin. Education and quality. The school goes back to school. São Paulo: Edições Loyola, 1994. 
[6] NEIVA, Evando. Dois Pontos Magazine - Force that generates change. Vol. 2, nº 16, 1994, Editora do Pitágoras, p. 112.

[7] OLIVEIRA, R. P.; ARAÚJO, G. C. Quality of teaching: a new dimension in the struggle for the right to education. Revista Brasileira de Educação, n. 28, p. 5-23, Jan-Apr. 2005.

[8] RINEHART, Gray. Quality Education. Milwaukee, Wisconsin, USA: ASQC Quality Press, 1993.

[9] SANDRINI, P. Marcos, GANDIN, Danilo, CRUZ, Carlos Henrique Carrilho, et. all. TOTAL QUALITY IN SCHOOL: Conservative change. In: Revista AEC, year 23, nº 92, jul./set. 1994.

\section{AUTHORS' BIOGRAPHY}

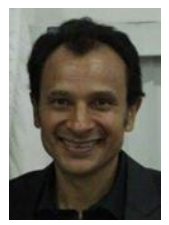

Frank Viana Carvalho, PhD in Philosophy at University of São Paulo, Brazil. Professor of Basic, Technical and Technological Education at the Federal Institute of Education, Science and Technology of São Paulo - Campus São Roque (IFSP-SRQ).

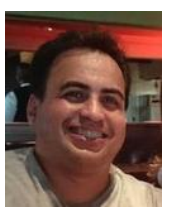

Ricardo dos Santos Coelho, $\mathrm{PhD}$ in Environmental Engineering at University of São Paulo, Brasil. Professor of Basic, Technical and Technological Education at the Federal Institute of Education, Science and Technology of São Paulo - Campus São Roque (IFSPSRQ).

Citation: Frank Viana Carvalho, Ricardo dos Santos Coelho. " Quality Education Management and Teaching Quality "International Journal of Humanities Social Sciences and Education (IJHSSE), vol 7, no. 4, 2020, pp. 1-6. doi: http://dx.doi.org/10.20431/2349-0381. 0704001.

Copyright: (c) 2020 Authors. This is an open-access article distributed under the terms of the Creative Commons Attribution License, which permits unrestricted use, distribution, and reproduction in any medium, provided the original author and source are credited. 